\title{
Niech prawo pracy pozostanie prawem pracy
}

1. Od początku zmiany ustroju społeczno-gospodarczego w Polsce jesteśmy świadkami ataków na prawo pracy ze strony neoliberalnych ekonomistów oraz pracodawców, których większość uważa, że jest ono najcięższą kulą u nogi przedsiębiorcy, hamującą rozwój przedsiębiorczości. Najbardziej kontestowana zawartość tej „kuli” to ograniczenia w zakresie rozwiązywania stosunku pracy, wynagrodzenie minimalne, regulacja czasu pracy i wypoczynku pracownika; zbyt rygorystyczne i kosztowne - ich zdaniem - są przepisy bhp oraz uprawnienia związane z rodzicielstwem. A do tego dochodzi kontrola i nadzór Państwowej Inspekcji Pracy nad przestrzeganiem przepisów tego prawa.

Niektórzy przedstawiciele lub rzecznicy środowiska pracodawców opowiadają się wprost za zniesieniem prawa pracy i powrotem do pełnej cywilistycznej swobody umów w zakresie zatrudnienia. Inni domagają się coraz dalej idącej jego liberalizacji, w czym osiągają znaczące sukcesy, głównie w postaci ciągłego „uelastyczniania” regulacji czasu pracy. W sukurs przychodzi im też coraz częściej orzecznictwo Sądu Najwyższego i Trybunału Konstytucyjnego, np. w odniesieniu do wypowiadania umów o pracę na czas określony z klauzulą dopuszczalności wypowiedzenia.

W oczekiwaniu na dalszą liberalizację bądź likwidację prawa pracy, prawodawcy, starając się zminimalizować koszty pracy, "radzą" sobie z nim na dwa sposoby: po pierwsze, tam, gdzie ono obowiązuje, tj. w stosunkach pracy, nagminnie łamią jego przepisy, o czym świadczą coroczne informacje Państwowej Inspekcji Pracy, doniesienia medialne i obserwacja życia codziennego; po drugie, unikają zatrudniania pracowników na podstawie umowy o pracę, zawierając $\mathrm{w}$ zamian umowy cywilnoprawne o świadczenie usług, albo zatrudniając ich faktycznie bez zawarcia jakiejkolwiek umowy.

* Profesor na Wydziale Prawa Uniwersytetu Marii Curie-Skłodowskiej w Lublinie. Sędzia Trybunału Konstytucyjnego. 
O ile $\mathrm{z}$ nieprzestrzeganiem $\mathrm{w}$ praktyce prawa pracy państwo może - chociaż niezbyt skutecznie - walczyć - przede wszystkim za pomocą Państwowej Inspekcji Pracy i sądów ${ }^{1}$, o tyle ucieczka od prawa pracy i przenoszenie stosunków zatrudnienia na grunt prawa cywilnego jest problemem znacznie trudniejszym do rozwiązania. W związku z tym niektórzy uczeni prawnicy też wieszczą koniec prawa pracy jako odrębnej gałęzi prawa i poddanie wszystkich stosunków zobowiązaniowych, w ramach których świadczona jest praca, prawu cywilnemu ${ }^{2}$. Specjaliści z zakresu prawa pracy, co skądinąd jest oczywiste, widzą konieczność jego utrzymania, chociaż w mniej lub bardziej zmodyfikowanej postaci, niektórzy - pod zmienioną nazwą - prawa zatrudnienia bądź prawa socjalnego.

Najbardziej palącym społecznym problemem rzutującym na przyszłość prawa pracy jest konieczność zapewnienia elementarnej ochrony prawnej osobom zatrudnionym „w nietypowych formach prawnych", w tym na podstawie umów cywilnoprawnych. Wiąże się to bezpośrednio z zakresem podmiotowym przyszłego prawa pracy. Najważniejsza zaś kwestia prawna to pojęcie stosunku (czy też stosunków) pracy. Trzecia sprawa, o której również dyskutuje się w kontekście przyszłości prawa pracy, to kwestia, czy ma być ono nadal skodyfikowane, czy może należałoby zrezygnować z Kodeksu pracy i poprzestać na odrębnych ustawach regulujących najważniejsze instytucje prawa pracy oraz układach zbiorowych pracy i innych autonomicznych źródłach prawa pracy. W tych właśnie sprawach wypowiadam się tutaj.

2. Zacznę od stwierdzenia, myślę oczywistego w gronie specjalistów prawa pracy, że nie wyobrażam sobie powrotu do cywilistycznej regulacji stosunków pracy i innych stosunków zatrudnienia, na zasadzie formalnej równości stron i szerokiej swobody umów (autonomii woli stron) ${ }^{3}$.

${ }^{1}$ Trzeba podkreślić, że sprawowanie nadzoru przez Państwową Inspekcję Pracy jest utrudnione m.in. przez to, że pracownicy w czasie kontroli bardzo często okłamują inspektorów pracy co do daty podjęcia i warunków zatrudnienia, gdyż wolą mieć pracę „na czarno" niż żadną. Dochodzenie zaś roszczeń pracowniczych przed sądami pracy bywa nieskuteczne z powodu braku dowodów wykonywania pracy i jej warunków, w związku z niechęcią współpracowników do składania zeznań, wynikającą z obawy o własne miejsce pracy. Nie należy też bagatelizować kryminalnych wręcz zachowań niektórych pracodawców, uciekających się do zastraszania, bicia, a nawet narażenia na śmierć pracowników upominających się o wynagrodzenie za wykonaną pracę, o czym donosiły w ostatnim roku media.

2 Tak np. Z. Radwański, Kodyfikacja prawa cywilnego, „Ruch Prawniczy, Ekonomiczny i Socjologiczny" 2009, nr 2, s. 131 i nast.; zob. też autorzy zagraniczni cytowani przez J. Borutę, w: Przyszłość prawa pracy, „Praca i Zabezpieczenie Społeczne” 2005, nr 4, s. 9 i 10.

3 Zob. W. Muszalski, Przyszłość prawa pracy, "Praca i Zabezpieczenie Społeczne” 2005, nr 7, a także W. Sanetra, Czy koniec prawa pracy, „Praca i Zabezpieczenie Społeczne” 2014, nr 8. 
W obecnym czasie nie przestały bowiem istnieć powody, dla których w wieku XIX wyjęto stosunki pracy najemnej z obrotu cywilnoprawnego. Mimo znaczących przemian w stosunkach przemysłowych, relacjach społecznych, rozwoju nauki i techniki, wciąż istnieje sprzeczność interesów i typowa jest nierównowaga między podmiotem korzystającym z cudzej pracy za pieniądze (pracodawcą), a tym, który świadczy tę pracę, aby móc utrzymać się przy życiu za zapłatę otrzymaną za swoją pracę. Przeciętny wykonawca pracy na rzecz innego podmiotu jest stroną słabszą od tej, która zawłaszcza owoce jego pracy w zamian za wynagrodzenie, i dlatego wymaga ochrony państwa. Państwo polskie (ustrojodawca) gwarantuje mu tę ochronę w art. 24 Konstytucji („Praca znajduje się pod ochroną Rzeczypospolitej Polskiej, Państwo sprawuje nadzór nad warunkami wykonywania pracy"). Ochrona pracy w ujęciu Konstytucji oznacza w istocie ochronę pracującego człowieka, gdyż nie można oderwać pracy od osoby jej wykonawcy ${ }^{4}$. Głównym instrumentem tej ochrony są semiimperatywne i imperatywne przepisy prawa pracy ${ }^{5}$. Mają one chronić pracownika, mającego, co do zasady, słabszą pozycję negocjacyjna, przed silniejszym - pracodawca, nie pozwalając temu ostatniemu na wykorzystanie umowy do ukształtowania warunków pracy i płacy poniżej poziomu uznanego przez ustawodawcę za minimalny.

Wbrew pojawiającej się nowej koncepcji, upatrującej głównej funkcji prawa pracy w ochronie pracownika (osoby poszukującej pracy) jako najsłabszego uczestnika rynku pracy przed wykluczeniem społecznym ${ }^{6}$, twierdzę, że istotą tej funkcji jest obecnie, tak jak było dawnej, skierowana do wewnątrz stosunku pracy, ochrona słabszego kontrahenta (pracownika) przed silniejszym (pracodawcą). Nie stoi to w sprzeczności z funkcjami zewnętrznymi prawa pracy, polegającymi na tym, że prawo to może (i powinno) być jednocześnie instrumentem polityki społecznej, w tym polityki rynku pracy, polityki prorodzinnej i walki z wykluczeniem społecznym. Powinno również odgrywać rolę pomocniczego narzędzia dobrej organizacji pracy, w interesie zarówno pracodawców, jak i pracowników, a także dla dobra publicznego.

${ }^{4}$ Zob. w tej sprawie T. Liszcz, Konstytucyjna zasada ochrony pracy, [w:] Prawo pracy. Refleksje i poszukiwania. Księga jubileuszowa Profesora Jerzego Wratnego, red. G. Uścińska, Warszawa 2013, s. 34 i nast.

${ }^{5}$ Przyznam się, że nie rozumiem poglądu A. Sobczyka, negującego istnienie norm semiimperatywnych $\mathrm{w}$ prawie pracy, związanego $\mathrm{z}$ koncepcją podziału norm indywidualnego prawa pracy na publiczne i prywatne, której to koncepcji też chyba nie pojmuję (A. Sobczyk, Prawo pracy w świetle Konstytucji RP, t. I, Teoria publicznego i prywatnego indywidualnego prawa pracy, Warszawa 2013, w szczególności s. 300-310).

${ }^{6}$ A. Sobczyk, Prawo pracy w świetle Konstytucji RP, t. I, zwłaszcza rozdział 1 oraz s. 293-300. 
Głęboka ingerencja państwa w stosunki pracy zarobkowej, mająca konstytucyjną podstawę $\mathrm{w}$ art. 20 i 24 oraz $\mathrm{w}$ innych postanowieniach ustawy zasadniczej, jest uzasadniona szczególnymi wartościami, z którymi wiążą się te stosunki (życie i zdrowie, wolność oraz godność człowieka pracującego, rodzina), oraz ich ogromnym znaczeniem społeczno-gospodarczym. Są to, według mnie, prywatnoprawne stosunki zobowiązaniowe, ale pod specjalnym nadzorem Państwa.

Uważam przy tym, że prawo pracy powinno nadal istnieć pod swoją dotychczasową nazwą. Jest ona na tyle pojemna, że może objąć - gdyby taka była decyzja ustawodawcy - wszelkie stosunki społeczne, w ramach których jest wykonywana praca zarobkowa na rzecz innego podmiotu niż wykonawca.

Dzisiejsze prawo pracy jest rozwiniętą kontynuacją ustawodawstwa fabrycznego, w znacznym stopniu wywalczonego przez robotników i okupionego ich ofiarami, także z życia. Reguluje ono przede wszystkim wymianę niezwykle cennego dobra (nie chcę powiedzieć towaru), jakim jest praca człowieka, za wynagrodzenie, które pozwala utrzymać się przy życiu pracownikowi i jego rodzinie. W sferze gospodarczej określa ono współpracę między dwoma koniecznymi elementami gospodarki rynkowej (kapitalistycznej), jakimi są praca i kapitał ${ }^{7}$. Z tych względów nie zga280 dzam się na „utopienie" prawa pracy w prawie socjalnym, obejmującym między innymi prawo ochrony lokatorów i konsumentów, a także pomoc czy opiekę społeczną?.

Nie widzę też potrzeby zmiany nazwy „prawo pracy” na "prawo zatrudnienia" ${ }^{\prime}$. Postulat takiej zmiany jest uzasadniany koniecznością objęcia przyszłym prawem pracy nie tylko - jak dotąd - stosunków pracy (dobrowolnie) podporządkowanej, lecz także innych „stosunków zatrudnienia", m.in. niektórych regulowanych dotąd przez prawo cywilne. Moim zdaniem, rozszerzenie zakresu obowiązywania prawa pracy nie musi, a zatem nie powinno, wiązać się ze zmianą nazwy tej gałęzi prawa, która - powtarzam - jest bardzo pojemna, a przy tym obrosła już tradycją i kojarzy się z określoną aksjologią. Odejście od obecnej nazwy mogłoby

${ }^{7} \mathrm{Na}$ temat relacji pracy i kapitału na gruncie ustawy zasadniczej zob. T. Liszcz, Praca i kapitał w Konstytucji Rzeczypospolitej Polskiej, [w:] Księga Jubileuszowa dedykowana profesor Ewie Gdulewicz w siedemdziesięciolecie urodzin, „Studia Iuridica Lublinensia” [Lublin] 2014, t. XXII, s. 253 i nast.

8 A. Sobczyk, Pracownicze i lokatorskie prawo socjalne - elementy wspólnoty aksjologicznej i konstrukcyjnej, [w:] Prawo pracy. Refleksje i poszukiwania..., s. 71; zob. też W. Muszalski, Prawo socjalne, Warszawa 2010, s. 11 i 12 oraz idem, Przyszłość prawa pracy...

${ }^{9}$ M. Gersdorf, Prawo zatrudnienia, Warszawa 2013, s. 29-34 oraz s. 169 i nast.; muszę zaznaczyć, że nie jest dla mnie jasne w tej koncepcji stwierdzenie, że jądrem przyszłego prawa zatrudnienia byłoby tradycyjne prawo pracy; zob. też J. Boruta, Przyszłość prawa pracy, „Praca i Zabezpieczenie Społeczne” 2005, nr 5, s. 8. 
być odczytane jako odejście także od tej tradycji i aksjologii, a tego - jak sądzę - nikt $z$ nas nie chce.

3. Przechodząc do następnej kwestii: „przyszłe prawo pracy skodyfikowane czy zdekodyfikowane?", mówię stanowcze "tak" dalszemu istnieniu Kodeksu (lub nawet dwóch kodeksów) pracy, chociaż, oczywiście, niekonieczne temu z $1974 \mathrm{r} .^{10}$ Skądinąd muszę jednak przyznać, że ten Kodeks, powstały w zupełnie innym ustroju politycznym i społeczno-gospodarczym, po kilkudziesięciu (podobno ponad 80) nowelizacjach, co do zasady spełnia swoją funkcję w nowych warunkach ustrojowych, chociaż nie odpowiada im w pełni i jest trudny w stosowaniu ${ }^{11}$.

Wiadomo, że w różnych krajach europejskich prawo pracy jest skodyfikowane albo „zdecentralizowane” i że istnienie albo brak Kodeksu pracy nie ma istotnego znaczenia dla skuteczności ochrony zapewnianej przez to prawo pracownikom. Decyzja co do kształtu legislacyjnego prawa pracy zależy od tradycji i kultury prawnej danego państwa. W naszym kraju mamy do czynienia ze słabą znajomością prawa i niską kulturą prawną. Polacy są też zmęczeni stale zmieniającymi się przepisami prawnymi i liczbą aktów normatywnych, trudną do opanowania nawet przez zawodowych prawników. Nie ma też dobrze rozwiniętego autonomicznego prawa pracy. W tej sytuacji jeden wiodący akt normatywny z zakresu prawa pracy - w miarę zupełny Kodeks pracy - ułatwia zapoznanie się z prawem pracy przede wszystkim pracownikom, ale także małym i średnim pracodawcom, nie mającym fachowej obsługi prawnej. Daje też poczucie stabilności i ładu w stosunkach pracy, ważne dla utrzymania pokoju społecznego.

4. Najtrudniejszym wyzwaniem, jakie staje obecnie przed ustawodawca, ale także przed nauką prawa pracy, która powinna wypracować propozycje dla ustawodawcy, jest zapewnienie chociażby elementarnej ochrony prawnej na wzór ochrony pracowników, osobom utrzymującym się z osobistej pracy, świadczonej na rzecz innych podmiotów, na innej podstawie prawnej niż stosunek pracy, lecz pozostających w zależności ekonomicznej od tego podmiotu. Nie ulega wątpliwości, że konstytucyjna zasada ochrony pracy zobowiązuje państwo (ustawodawcę) do objęcia tą ochroną - chociaż niekoniecznie identyczną w stosunku do różnych prawnych form zarobkowania - wszystkich osób utrzymujących się z własnej

${ }_{10}$ Za (re)kodyfikacją opowiedzieli się, między innymi, T. Zieliński, Kodyfikacja prawa pracy. Watpliwości i dylematy, "Praca i Zabezpieczenie Społeczne” 2003, nr 11, s. 4 i nast.; W. Sanetra, Co dalej z kodyfikacja (rekodyfikacja) prawa pracy, „Praca i Zabezpieczenie Społeczne" 2008, nr 3.

11 Skrajnie odmienną ocenę obowiązującego Kodeksu pracy wyraziła H. Bochniarz, prezydentka Konfederacji Pracodawców Prywatnych „Lewiatan”, która w dyskusji redakcyjnej z okazji 40-lecia uchwalenia Kodeksu nazwała go potworkiem prawnym, "Gazeta Prawna" z 26 czerwca 2014 r. 
pracy $^{12}$. Zaniechanie aktywności państwa w celu zapewnienia tej ochrony nie-pracownikom oznacza niewywiązanie się z tego obowiązku ${ }^{13}$.

W związku z tym zadaniem wyłaniają się dwa główne problemy. Po pierwsze, ustalenie minimum uprawnień osób wykonujących pracę zarobkową na rzecz innego podmiotu, nie będących pracownikami. Po drugie, miejsce i sposób uregulowania ochrony prawnej takich osób.

Co do pierwszej kwestii, wydaje się, że jest zgoda na to, aby ta pula minimalnych uprawnień związanych z niepracowniczym zatrudnieniem obejmowała: ochronę życia i zdrowia (to $w$ istocie obowiązuje już obecnie z mocy art. 304 k.p.), prawo do wypoczynku, a więc określenie maksymalnych norm czasu pracy i minimalnych norm wypoczynku; minimalne wynagrodzenie za pracę, ochronę przed nagłą (bez odpowiedniego uprzedzenia) utratą zatrudnienia, wymóg zawarcia umowy lub potwierdzenia jej treści na piśmie oraz pewną ochronę związaną $\mathrm{z}$ macierzyństwem. Ze względu na art. 59 Konstytucji i liczne umowy międzynarodowe konieczne jest przyznanie wszystkim utrzymującym się z własnej pracy (ludziom pracy) prawa koalicji ${ }^{14}$. Ponadto należy wyposażyć Państwową Inspekcję Pracy w kompetencje kontroli i nadzoru nad warunkami takiej pracy oraz poddać spory o roszczenia ze stosunku zatrudnienia sądom pracy. Uważam, że nie należy postulować przyznania osobom wykonującym niepracownicze zatrudnienie dalszych uprawnień niezbędnych w celu zapobiegania ich wykluczeniu społecznemu ${ }^{15}$. Przyznanie wszystkim osobom wykonującym pracę poza stosunkiem pracy uprawnień bardzo zbliżonych do tych, które przysługują pracownikom, przekreśliłoby sens istnienia różnych prawnych form zatrudnienia. Przy tym prawo pracy nie jest jedynym, ani, moim zdaniem, nawet głównym, instrumentem polityki przeciwdziałania wykluczeniu, choć niewątpliwie jest to instrument istotny. W gospodarce rynkowej, nawet gdy jest to - jak to stanowi art. 20 Konstytucja RP - społeczna gospodarka rynkowa, nie można nadmiernie obciążać prywatnych podmiotów zatrudniających obowiązkami socjalnymi.

${ }^{12}$ Zgadzam się w tej sprawie całkowicie z poglądem A. Sobczyka, Prawo pracy w świetle Konstytucji RP, t. I, s. 53 i nast. Taki sam pogląd wyraziłam wcześniej m.in. w: Konstytucyjna zasada ochrony pracy..., s. 34 i nast.

${ }^{13}$ Najostrzej ocenia ten stan rzeczy A. Sobczyk, określając go mianem deliktu konstytucyjnego: Prawo pracy w świetle Konstytucji RP, t. I, s. 3.

${ }_{14}$ Zob. m.in. A. Patulski, Praca niepewna jako przedmiot zmian na współczesnym rynku pracy, [w:] Prawo pracy. Refleksje i poszukiwania..., s. 91 oraz J. Wratny, Problemy ochrony pracowników elastycznych formach zatrudnienia, „Praca i Zabezpieczenie Społeczne” 2007, nr 7, s. 18; ten ostatni autor postuluje ochronę kobiet w ciąży i w pierwszym okresie po porodzie.

${ }_{15}$ Tak, jak się wydaje, A. Sobczyk, Prawo pracy w świetle Konstytucji RP, t. I, s. 147 oraz s. 159. 
Ochronę pracy wykonywanej w ramach niepracowniczego zatrudnienia można wprowadzić różnymi prawnymi sposobami. Po pierwsze, tak rozszerzyć pojęcie stosunku pracy, by objęło ono także inne formy zatrudnienia niż praca (dobrowolnie) podporządkowana ${ }^{16}$. Po drugie, nie zmieniając istoty stosunku pracy, objąć zakresem obowiązywania prawa pracy, poza dotychczasowym tradycyjnym stosunkiem pracy, także niektóre inne stosunki zatrudnienia, zbliżone do stosunku pracy (tzw. nietypowe stosunki pracy), a poza tym, na zasadzie ekspansji prawa pracy, rozciągnąć niektóre jego przepisy na zatrudnienie cywilnoprawne i ewentualnie administracyjnoprawne. Po trzecie, wprowadzić określone regulacje ochronne do przepisów prawa cywilnego, dotyczących umów oświadczenie usług ${ }^{17}$. Po czwarte, wydać odrębne ustawy („międzygałęziowe”), regulujące, stosownie do potrzeb, poszczególne rodzaje niepracowniczego zatrudnienia $^{18}$.

Spośród tych kilku sposobów za najwłaściwszy uważam ten polegający na (umiarkowanym) rozszerzeniu zakresu obowiązywania prawa pracy (Kodeksu pracy). Tę metodę zastosowała Komisja Kodyfikacyjna Prawa Pracy w Projekcie Kodeksu pracy, opracowanym w 2006 r. ${ }^{19} \mathrm{~W}$ art. 1 Projekt tak określa zakres obowiązywania Kodeksu pracy: „§ 1. Kodeks pracy [...] reguluje zatrudnienie $\mathrm{w}$ ramach stosunku pracy oraz stosunki prawne $\mathrm{z}$ nim związane. $\S 2$. W zakresie niezbędnym do ochrony pracy Kodeks reguluje zatrudnianie $\mathrm{w}$ ramach innych stosunków prawnych niż stosunek pracy".

Projekt pozostaje przy dotychczasowej definicji stosunku pracy, nieco ją tylko ulepszając: „Art. $44 \S 1$. Przez nawiązanie stosunku pracy pracownik zobowiązuje się do osobistego świadczenia pracy podporządkowanej określonego rodzaju, na rzecz pracodawcy i jego ryzyko, a pracodawca do zatrudniania pracownika za wynagrodzeniem".

Słusznie, moim zdaniem, zastąpiono w tej definicji kierownictwo pracodawcy podporządkowaniem pracownika, gdyż podporządkowanie jest kategorią szerszą pozwalającą na objęcie nią także tych rodzajów prac,

16 Pogląd taki w najbardziej radykalnej formie głosił A. Chobot, Nowe formy zatrudnienia. Kierunki rozwoju i nowelizacji, Warszawa 1997, s. 192 i nast. Twierdził on, że przyszłe prawo pracy powinno obejmować „,wszelkie formy pracy zależnej, od pracy jednostronnej do zależnej w tym jedynie sensie, iż wytwory pracy są sprzedawane niejako za pośrednictwem silniejszego gospodarczo partnera".

17 Przykładem zastosowania tego rozwiązania są zmiany wprowadzone do przepisów Kodeksu cywilnego o umowie agencyjnej ustawą z dnia 26 lipca 2000 r. o zmianie Kodeksu cywilnego, DzU, 2000, nr 74, poz. 857.

18 Za tym rozwiązaniem opowiada się, jak sądzę, W. Muszalski, Przyszłość prawa pracy..., s. 3 i nast.

${ }^{19}$ Kodeks pracy. Zbiorowy Kodeks pracy. Projekty, Katowice 2010. 
w których nie występuje lub występuje w minimalnym nasileniu bezpośrednie kierowanie praca przez pracodawcę za pomocą poleceń. Z tych samych względów za trafne uważam pominięcie w projektowanej definicji, jako odrębnej ceny stosunku pracy, związania pracownika miejscem i czasem wykonywania pracy; co do zasady to związanie wynika z podporządkowania pracownika w procesie pracy, chociaż nie jest cechą konieczną (zadaniowy czas pracy, telepraca).

Nie zgadzam się z tezą głoszoną głównie przez zachodnich autorów, jakoby tradycyjny model stosunku pracy, w ramach którego następowała wymiana "podporządkowanie za bezpieczeństwo" (ekonomiczne, socjalne), całkowicie się przeżył ${ }^{20}$. Moim zdaniem, jest on nadal w pełni przydatny przede wszystkim w szerokim obszarze produkcji i usług materialnych oraz na szeregowych stanowiskach urzędniczych, gdzie trudno sobie nawet wyobrazić inny sposób organizacji pracy niż oparty na stosunku pracy podporządkowanej. Nie ulega przy tym wątpliwości, że większość ludzi nie ma natury kreatywnego twórcy - przedsiębiorcy lub artysty, zdolnego samodzielnie zorganizować sobie działalność zawodową.

Poza tradycyjnym stosunkiem pracy podporządkowanej, do przedmiotu prawa pracy, według Projektu, należą tzw. nietypowe stosunki pracy, wykazujące pewne odstępstwa od klasycznego wzorca stosunku pracy lub charakteryzujące się dodatkowymi specyficznymi cechami (Księga szósta Projektu). Do nietypowych stosunków pracy Projekt zalicza: pracę tymczasowa, telepracę, staż zawodowy, zarządzanie zakładem pracy, pracę nakładcza, pracę domową pracę rodzinną oraz umowę o pracę spółdzielczą. Do nietypowych stosunków pracy, co do zasady, miałoby się stosować wszystkie przepisy Kodeksu pracy dotyczące stosunku pracy z wyjątkiem wyłączonych od stosowania (expressis verbis bądź przez odmienną regulację określonych spraw) przez przepisy szczególne odnoszące się do danego nietypowego stosunku pracy.

Poza właściwym przedmiotem Kodeksu pracy (prawa pracy), Projekt pozostawia tzw. zatrudnienie niepracownicze - na podstawie umowy oraz na kierowniczych stanowiskach państwowych, któremu jednak poświęca przepisy Księgi siódmej, zapewniające tej kategorii zatrudnionych pewne uprawnienia quasi pracownicze, ze względu na to, że „art. 24 Konstytucji zobowiązuje państwo do należytej ochrony wszelkiej pracy i nadzoru nad warunkami jej wykonywania" (uzasadnienie Projekt, pkt 10).

Projekt nie wymienia nazw umów cywilnoprawnych obejmowanych fragmentaryczną ochroną prawa pracy. Może to więc być zarówno umowa nazwana (zlecenie, dzieło, agencja), jak i nienazwana, o ile spełnia warunki

${ }^{20}$ Zob. J. Boruta, W sprawie przyszłości prawa pracy („Praca i Zabezpieczenie Społeczne" 2005, nr 4) i cytowani tam autorzy zachodnioeuropejscy. 
określone $\mathrm{w}$ tych przepisach jako przesłanki obowiązywania tej ochrony. Zgodnie z art. 462 Projektu, przepisy Kodeksu o zatrudnieniu niepracowniczym na podstawie umowy miałyby być stosowane do osoby zatrudnionej na podstawie umowy, innej niż umowa o pracę (typowa bądź nietypowa), wykonującej osobiście (lub z pomocą członków rodziny pozostających z nią we wspólnym gospodarstwie domowym), na rzecz jednego podmiotu zatrudniającego - pracę ciągłą lub powtarzającą się, za wynagrodzeniem przekraczającym połowę wynagrodzenia minimalnego. Przepisy te miałyby być stosowane także $\mathrm{w}$ razie wykonywania pracy o takim charakterze na rzecz podmiotu zatrudniającego, nie będącego jedynym podmiotem zatrudniającym tę osobę, o ile uzyskuje ona od niego większą część swego łącznego wynagrodzenia, przekraczającą połowę wynagrodzenia minimalnego. Chodzi więc o sytuacje, w których wykonawca pracy jest uzależniony ekonomicznie od podmiotu zatrudniającego.

Ochrona tego rodzaju zatrudnienia miałaby obejmować m.in. obowiązek potwierdzenia na piśmie treści umowy zawartej ustnie, ustanowienie minimalnych okresów wypowiedzenia, ograniczenie wypowiadania umowy kobiecie $\mathrm{w}$ okresie ciąży i w ciągu ośmiu tygodni po porodzie, prawo do bezpiecznych i higienicznych warunków pracy, prawo do bezpłatnego urlopu wypoczynkowego oraz do urlopu macierzyńskiego, a także możliwość objęcia tak zatrudnionych osób układami zbiorowymi pracy i innymi autonomicznymi źródłami prawa pracy tudzież objęcie ich właściwością sądów pracy.

Do osób pozostających w zatrudnieniu niepracowniczym na kierowniczych stanowiskach (Prezydent RP, premier i ministrowie) - według Projektu - miałyby być odpowiednio stosowane przepisy Kodeksu pracy dotyczące ochrony wynagrodzenia za pracę, urlopów wypoczynkowych, ochrony rodzicielstwa oraz ochrony pracy. Projekt przewiduje również odpowiednie stosowanie przepisów Kodeksu do zatrudnienia funkcjonariuszy Policji i pozostałych służb mundurowych w sprawach nieuregulowanych w dotyczących ich przepisach odrębnych. Według Projektu, spory ze stosunku niepracowniczego zatrudnienia tych wszystkich osób miałyby rozstrzygać sądy pracy.

Niewątpliwie można kwestionować wiele szczegółowych rozwiązań Projektu Kodeksu pracy, ale uważam, że gdy chodzi o zaproponowany w nim zakres obowiązywania Kodeksu (i całego prawa pracy) i realizację postulatu objęcia ochroną prawa pracy także osób pozostających w niepracowniczym zarobkowym zatrudnieniu, Komisja Kodyfikacyjna obrała właściwy kierunek. Projekt może więc stanowić dobrą podstawę do dyskusji na ten temat w środowisku naukowym oraz pracodawców i związków zawodowych. 
5. W uzasadnieniu Projektu Kodeksu pracy (pkt 10) wyrażono zapatrywanie, że Projekt, obejmując osoby wykonujące niepracownicze zatrudnienie pewnym zakresem swoich przepisów ochronnych, "zapobiega stosowaniu ich $\mathrm{w}$ celu obejścia przepisów prawa pracy". Uważam to stwierdzenie za nadmiernie optymistyczne. Niepracownicze (umowne) zatrudnienie, mimo objęcia go częściową ochroną prawa pracy, i tak będzie znacznie mniej kosztowne dla pracodawcy niż praca otrzymywana $\mathrm{w}$ ramach stosunku pracy. Toteż nadal będzie istniał powód do ukrywania stosunku pracy pod pozornymi umowami o zatrudnienie niepracownicze, chociaż może to się dziać na mniejszą niż teraz skalę.

Obecnie patologia polegająca na zatrudnianiu bez żadnej ujawnionej umowy oraz na podstawie oficjalnej umowy cywilnoprawnej, pod którą kryje się w istocie stosunek pracy w zakresie obowiązków, lecz bez większości uprawnień pracowniczych, występuje nagminnie. W celu oczyszczenia przed pola dla rekodyfikacji, należałoby najpierw rozprawić się z tą patologia, dającą wymierne korzyści nieuczciwym pracodawcom kosztem wyzyskiwanych pracowników. Praktyka ta umożliwia też nieuczciwą konkurencję tych pracodawców na rynku dóbr i usług.

Instrumentem prawnym, który, moim zdaniem, byłby pomocny przy zwalczaniu wspomnianej patologii, jest prawne domniemanie istnienia stosunku pracy w sytuacji, gdy charakter stosunku zatrudnienia jest sporny między stronami, a stosunek ten wykazuje w praktyce przynajmniej niektóre cechy konstytutywne dla stosunku pracy.

Wprowadzenie takiego domniemania proponowała $\mathrm{w}$ czasie prac Nadzwyczajnej Komisji Sejmowej do Spraw Kodeksu Pracy nad „dużą" nowelizacją Kodeksu pracy (sfinalizowaną ustawą z 2 lutego 1996 r.) Państwowa Inspekcja Pracy, a ja próbowałam ją w tym wspierać, niestety, bez rezultatu. Przeciwko temu pomysłowi rozpętali istną burzę przedstawiciele i eksperci pracodawców, niektórzy adwokaci, a także niektórzy specjaliści prawa cywilnego oraz prawa pracy. Zarzucano mu zamiar wyeliminowania $z$ obrotu prawnego cywilnoprawnych umów o świadczenie usług i uśmiercenia wolnych zawodów, przez "swoistą derogację odpowiednich przepisów prawa cywilnego", a także straszono wizją zalewu sądów sprawami o ustalenie stosunku pracy ${ }^{21}$.

Moim zdaniem, zarzuty te wynikają z niezrozumienia istoty domniemania stosunku pracy lub ze złej woli. Jest oczywiste, że domniemanie, o którym mowa, w żaden sposób nie może dotyczyć sytuacji, gdy stro-

${ }^{21}$ Zob. np. Ż. Semprich, Gwałtowna śmierć wolnych zawodów, "Rzeczpospolita" z 30 listopada 1994 r.; tejże autorki: Ochrona iluzoryczna i na krótka metę, "Rzeczpospolita” z 29 grudnia 1994 r. Również obecnie wizja wprowadzenia domniemania budzi gwałtowny sprzeciw niektórych - często tych samych - autorów - zob. M. Gersdorf, Czy powraca widmo domniemania istnienia stosunku pracy?, „Praca i Zabezpieczenie Społeczne” 2011, nr 4. 
ny zawarły umowę o treści odpowiadającej nazwanej umowie cywilnoprawnej, w szczególności umowie o dzieło lub umowie zlecenia i realizują ją zgodnie z tą treścią. Nie ma ono znaczenia także wtedy, gdy została zawarta nienazwana umowa o świadczenie usług, która nie stwarza organizacyjnej zależności wykonawcy usług od zlecającego. Domniemanie miałoby zastosowanie wyłącznie wtedy, gdy (oficjalnie) cywilnoprawna umowa zawiera postanowienia zobowiązujące "usługodawcę" do wykonywania obowiązków na sposób pracowniczy (w warunkach podporządkowania organizacyjnego), albo, nie zawierając takich postanowień, jest $\mathrm{w}$ praktyce $\mathrm{w}$ taki sposób realizowana, $\mathrm{z}$ równoczesnym pozbawieniem tegoż „usługodawcy” wszystkich bądź większości uprawnień pracowniczych.

Chodzi przy tym o domniemanie obalalne (praesumptio iuris tantum), a nie o domniemanie niewzruszalne (praesumptio iuris ac de iure) ani o fikcję prawną. Jego istota sprowadza się do zmiany rozkładu ciężaru dowodu co do natury danego stosunku zobowiązaniowego. W razie sporu w tym zakresie, po uprawdopodobnieniu, że w grę może wchodzić stosunek pracy (wykazaniu istnienia niektórych cech takiego stosunku), ciężar dowodu mającego obalić to domniemanie spoczywałby na podmiocie zainteresowanym jego obaleniem, czyli z reguły na podmiocie zatrudniającym.

Na nieporozumieniu lub złej woli oparty jest również wysuwany niekiedy zarzut, jakoby wprowadzenie domniemania stosunku pracy zmuszało do stosowania przepisów prawa pracy do umowy cywilnoprawnej, dopóki nie zostanie przed sądem udowodniony jej cywilnoprawny charakter. Sąd nie działa przecież z urzędu. Dopiero gdy między stronami powstanie spór co do charakteru umowy, np. w związku z żądaniem przez pracownika udzielenia mu urlopu wypoczynkowego, na żądanie strony lub innego uprawnionego podmiotu (np. prokuratora) sąd powinien rozstrzygnąć spór.

Domniemanie ułatwiłoby też sprawowanie kontroli i nadzór nad warunkami pracy przez Państwową Inspekcję Pracy, zwłaszcza ściganie wykroczenia przeciwko prawu pracy, o którym mowa w art. 281 pkt 1 k.p. („Kto będąc pracodawcą lub działając w jego imieniu: a) zawiera umowę cywilnoprawną $\mathrm{w}$ warunkach, $\mathrm{w}$ których zgodnie $\mathrm{z}$ art. $22 \S 1$ powinna być zawarta umowa o pracę [...] podlega karze grzywny od 1000 do 30000 zł”).

Przeciwnikom wprowadzenia do polskiego prawa domniemania istnienia stosunku pracy należy przypomnieć, że jego wprowadzenie do ustawodawstw państw członkowskich zaleca Międzynarodowa Organizacja Pracy w zaleceniu nr 198 z 15 czerwca 2006 r. dotyczącym stosunku pracy. Konferencja Ogólna MOP, uwzględniając między innymi "trudności w ustaleniu, czy stosunek pracy istnieje w sytuacji, gdy prawa i obowiązki zainteresowanych stron nie są jasne, bądź też gdy podjęto 
próby ukrycia stosunku pracy [...], [uznała, że] należy zająć się sprawą niepewności istnienia stosunku pracy w celu zagwarantowania uczciwej konkurencji i efektywnej ochrony pracowników pozostających w stosunku pracy w sposób zgodny z krajowym prawem i krajową praktyką (preambuła)".

Według zalecenia, krajowa polityka powinna zwalczać ukrywanie stosunku pracy „w kontekście, na przykład, innych stosunków, które moga polegać na zastosowaniu innej formy postanowień umownych, ukrywających prawdziwy status prawny, pamiętając, że ukryty stosunek pracy występuje wówczas, gdy pracodawca nie traktuje osoby tak jak pracownika, ukrywając jego lub jej prawdziwy status prawny jako pracownika; taka sytuacja może zaistnieć $\mathrm{w}$ momencie, gdy postanowienia umowne skutkują pozbawieniem pracowników należnej im ochrony (pkt 4a)".

Aby ułatwić ustalenie istnienia stosunku pracy, państwa członkowskie powinny, zgodnie z zaleceniem, między innymi, „,ustanowić domniemanie prawne, że stosunek pracy istnieje wówczas, gdy obecny jest jeden lub więcej określonych wskaźników" (pkt 11b). Powinny też rozważyć określenie w swoim ustawodawstwie, bądź w inny sposób, szczególnych czynników decydujących o stosunku pracy. Zalecenie wskazuje w dalszym ciąu przykładowy zestaw takich czynników.

W kolejnym punkcie (14) zalecenie stwierdza, że rozwiązywanie sporów dotyczących istnienia oraz warunków stosunku pracy powinno należeć do kompetencji sądów pracy lub innych sądów, bądź organów arbitrażowych, do których pracownicy i pracodawcy mają rzeczywisty dostęp.

Uważam, że należałoby się poważnie zastanowić nad wdrożeniem tego zalecenia w Polsce.

\section{Bibliografia}

Boruta I., Przyszłość prawa pracy, „Praca i Zabezpieczenie Społeczne” 2005, nr 4.

Chobot A., Nowe formy zatrudnienia. Kierunki rozwoju i nowelizacji, Warszawa 1997.

Gersdorf M., Czy powraca widmo domniemania istnienia stosunku pracy?, „Praca i Zabezpieczenie Społeczne" 2011, nr 4.

Gersdorf M., Prawo zatrudnienia, Warszawa 2013.

Liszcz T., Konstytucyjna zasada ochrony pracy, [w:] Prawo pracy. Refleksje i poszukiwania, Ksiegga jubileuszowa Profesora Jerzego Wratnego, red. G. Uścińska, Warszawa 2013.

Liszcz T., Praca i kapitał w Konstytucji Rzeczypospolitej Polskiej, [w:] Księga Jubileuszowa dedykowana profesor Ewie Gdulewicz w siedemdziesięciolecie urodzin, „Studia Iuridica Lublinensia" [Lublin] 2014, t. XXII.

Muszalski W., Prawo socjalne, Warszawa 2010.

Muszalski W., Przyszłość prawa pracy, „Praca i Zabezpieczenie Społeczne” 2005, nr 7.

Patulski A., Praca niepewna jako przedmiot zmian na współczesnym rynku pracy, [w:] Prawo pracy. Refleksje i poszukiwania, Ksiegga jubileuszowa Profesora Jerzego Wratnego, red. G. Uścińska, Warszawa 2013. 
Radwański Z., Kodyfikacja prawa cywilnego, „Ruch Prawniczy, Ekonomiczny i Socjologiczny" 2009, nr 2.

Sanetra W., Co dalej z kodyfikacja (rekodyfikacja) prawa pracy, „Praca i Zabezpieczenie Społeczne" 2008, nr 3.

Sanetra W., Czy koniec prawa pracy, „Praca i Zabezpieczenie Społeczne” 2014, nr 8.

Sobczyk A., Pracownicze i lokatorskie prawo socjalne - elementy wspólnoty aksjologicznej i konstrukcyjnej, [w:] Prawo pracy. Refleksje i poszukiwania, Księga jubileuszowa Profesora Jerzego Wratnego, red. G. Uścińska, Warszawa 2013.

Sobczyk A., Prawo pracy w świetle Konstytucji RP, t. I, Teoria publicznego i prywatnego indywidualnego prawa pracy, Warszawa 2013.

Wratny J., Problemy ochrony pracowników elastycznych formach zatrudnienia, „Praca i Zabezpieczenie Społeczne" 2007, nr 7.

Zieliński T., Kodyfikacja prawa pracy. Watpliwości i dylematy, „Praca i Zabezpieczenie Społeczne" 2003, nr 11.

\section{Let Labour Law Remain Labour Law}

\section{Summary}

Since the introduction of market economy in Poland neoliberal economists and employers, as well as their organizations, have perceived this branch of law as a major hindrance to economic growth, because the excessive - in their view - protection accorded to employees by labour law significantly increases labour costs. Some of them go as far as demanding abolition of labour law, some want it considerably more liberal.

A currently commonplace phenomenon is 'flight' from the labour law regime by employing workers on the basis of civil law agreements, which usually define the duties of workers in a way which closely resembles employment, while depriving them of the majority of employee rights.

In this context, there is an ongoing discussion in labour law literature about the future of labour law. Some participants are in favour of replacing the current labour law, which protects only employees in the strict sense, with work relations' law, which would grant protection - in varying degrees - to all workers providing work to another entity for remuneration, regardless of the legal form.

This writer supports keeping labour law, based on the existing principles, but covering, apart from typical relationships of employment, certain less frequent work relationships (e.g. outwork, homework, telework), which would enjoy different levels of protection. 